\title{
Regional liquefaction susceptibility mapping in the Himalayas using geospatial data and AHP technique
}

\author{
Ramesh Pudi ${ }^{1}$, Tapas R. Martha ${ }^{1}$, Priyom Roy ${ }^{1, *}$, K. Vinod Kumar ${ }^{1}$ and \\ P. Rama Rao ${ }^{2}$ \\ ${ }^{1}$ Geosciences Group, National Remote Sensing Centre, Indian Space Research Organisation, Hyderabad 500 037, India \\ ${ }^{2}$ Department of Geophysics, College of Science and Technology, Andhra University, Visakhapatnam 530003 , India
}

Liquefaction susceptibility (LS) assessment is a necessary input for seismic zonation studies. LS can be done using geospatial models by integration of thematic layers. In this study, we have used analytical hierarchy process for integration of thematic layers (e.g. water table depth, peak horizontal acceleration, etc.) to generate a regional LS map for Uttarakhand and Himachal Pradesh in India. The final map was classified as liquefaction-likely, liquefaction-possible and liquefaction-not-likely zones. Results show Doon valley and Himalayan foothills are more prone to $\mathrm{LS}$ than the higher Himalayas.

Keywords: Analytical hierarchy process, earthquakes, geospatial data, liquefaction susceptibility.

SoIL liquefaction describes a phenomenon whereby a saturated or partially saturated soil substantially loses its strength and stiffness in response to an applied stress, usually earthquake shaking, causing it to behave like a liquid $^{1}$. Liquefaction effects have caused extensive damage worldwide during major earthquakes (Alaska in 1964; Niigata, Japan in 1964; Loma Prieta, California in 1989; Kobe, Japan in 1995; and Chi-Chi, Taiwan in 1999). As a consequence of ground shaking due to these earthquakes, soil liquefaction and failure of slope, civil formations and foundation occurred pervasively ${ }^{2}$. Subsequent to the above-mentioned earthquakes, there have been many studies which have improved our understanding of earthquake-induced liquefaction ${ }^{3-7}$.

Liquefaction susceptibility (LS) also depends on the stratigraphy of the affected area. For example, younger Holocene deposits are more susceptible to liquefaction than older Pleistocene deposits because the older features show more cementation among their particles ${ }^{8}$. Liquefaction can be triggered by quick deformation along discrete horizons, such as landslides and lateral spreads 9 . Liquefaction is strongly influenced by age and physical properties of the geologic unit, water table depth (WTD) and permeability of the layer ${ }^{10,11}$. In a study carried out on

\footnotetext{
*For correspondence. (e-mail: roy.priyom@gmail.com)
}

liquefaction, it was observed that its occurrence commonly coincides with topography and proximity to a river ${ }^{12}$.

The contribution of geology and geomorphology to LS has been examined by several workers ${ }^{4,13}$. These correlations were confirmed during the 1990 Luzon earthquake in the Philippines during which the worst affected areas were back swamps, river channels, sand-spits and deltas $^{14}$. Along the rivers, groundwater level is shallow and deposition of sand is more due to the presence of active floodplains. This may cause sand boils and lateral spreading along the river ${ }^{15}$. It has been observed that during the 2011 Van (Turkey) earthquake, houses located on loose alluvial deposits along Karasu River at a foothills were damaged as a result of lateral spreading cracks ${ }^{16}$.

Most of the liquefaction probability assessment or liquefaction potential index (LPI) studies have been done using detailed geological mapping, standard penetration test (SPT) or cone penetration test (CPT) with WTD information $^{17,18}$. These assessments are mainly carried out by ground surveys, which are expensive. Assessment of regional liquefaction hazard is necessary for earthquake hazard mitigation. These maps can be prepared by geospatial analysis, which has been demonstrated by several researchers ${ }^{19-24}$. Recently, an updated geospatial liquefaction model for global application was developed using peak ground velocity (PGV), peak ground acceleration (PGA), average shear wave velocity up to $30 \mathrm{~m}$ depth $\left(V_{\mathrm{s}} 30\right)$, distance to the coast, distance to the river, distance to a water body, WTD, compound topographic index, precipitation and elevation above the nearest water ${ }^{19}$. Assessment of liquefaction susceptibility index in earthquake-prone areas has immense importance, especially if those areas are densely populated. For example, in the tectonically active Himalayan mountain belt, a highmagnitude earthquake can trigger large-scale liquefaction along the foothill regions which are comprised of Quaternary deposits.

The foothills of the Himalayas have shallow groundwater table and alluvium material. The extent of fluvial deposits along the valleys makes the entire region vulnerable to liquefaction. The foothills of the Himalaya have recorded two liquefaction incidents during the 1803 


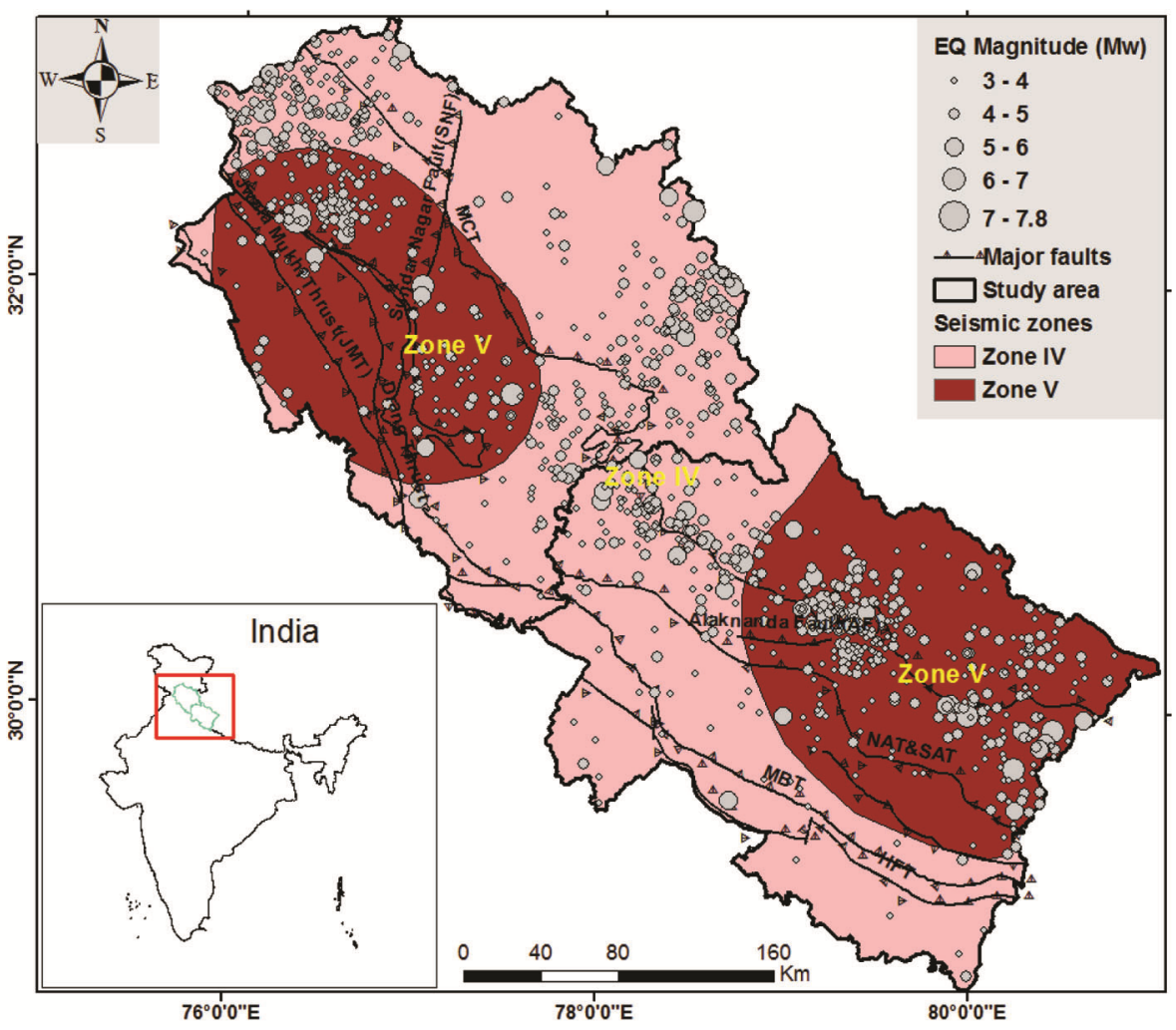

Figure 1. Map of India showing the study area comprising Uttarakhand and Himachal Pradesh. Seismicity and major faults such as the Himalayan Frontal Thrust (HFT), Main Boundary Thrust (MBT), Main Central Thrust (MCT), North and South Almora Thrust (NAT\&SAT), Alakananda Fault, Drag Thrust, Jwalamukhi Thrust and Sundernagar Faults are shown.

Garhwal earthquake $\left(M_{W} \sim 7.5\right)^{25,26}$. The 1897 Shillong earthquake resulted in several liquefaction incidents along the Brahmaputra River ${ }^{27}$. Earthquakes in the Central Himalayas such as the 1934 Bihar-Nepal earthquake and the event in 1988 have triggered several liquefactions incidents in the Indo-Gangetic Plains of Uttar Pradesh and North Bihar ${ }^{28}$.

As discussed above, liquefaction is mainly controlled by factors such as earthquake intensity, magnitude, duration, geomorphology, lithology, soil, WTD, PGV, geological discontinuities, etc. In the present study, we have prepared LS map of Uttarakhand and Himachal Pradesh by geospatial integration of the above-mentioned parameters.

\section{Geology and seismicity of the study area}

It is well known that the Himalayan region is tectonically active due to collision between the Indian and the Eurasian plates. Uttarakhand and Himachal Pradesh represent the significant geological configurations of the Himalayas encompassing five distinct subdivisions based on tectonic, lithology and major north-dipping thrusts ${ }^{29-31}$. In these two states, a major geographic extent of the region comprises the Lesser Himalayas and the Sub-
Himalayas, which are mainly unconsolidated (alluvium gravel/sand/silt-dominant), semi-consolidated (sandstone/ pebble/conglomerate) rocks, thus making the region prone to liquefaction. According to the seismic zonation map of India, this region falls under seismic zones IV and $\mathrm{V}$ which are highly prone to future earthquakes (Figure $1)^{32}$. The region has experienced several earthquakes such as the 1803 Garhwal-Kumaun $\left(M_{W} \sim 7.5\right), 1905$ Kangra (7.8 $\left.M_{W}\right), 1975$ Kinnaur $\left(6.1 M_{W}\right), 1991$ Uttarkashi $\left(6.8 M_{W}\right)$ and 1999 Chamoli $\left(6.6 M_{W}\right)$ with continuous small-scale seismicity (Figure 1). The major rivers of India such as the Ganga, Yamuna and their tributaries pass through this region, resulting in fluvial valleys with shallow groundwater levels. The region is also prone to landslides which are susceptible to liquefaction. Therefore, evaluation of seismic hazard, landslide, flood and liquefaction effects is of relevance to disaster risk reduction and mitigation.

\section{Materials and methods}

We have considered factors which favour liquefaction and can be easily derived on a regional scale. Age of the geological deposits and their geomorphology are important for LS. Liquefaction occurrence is commonly associated 

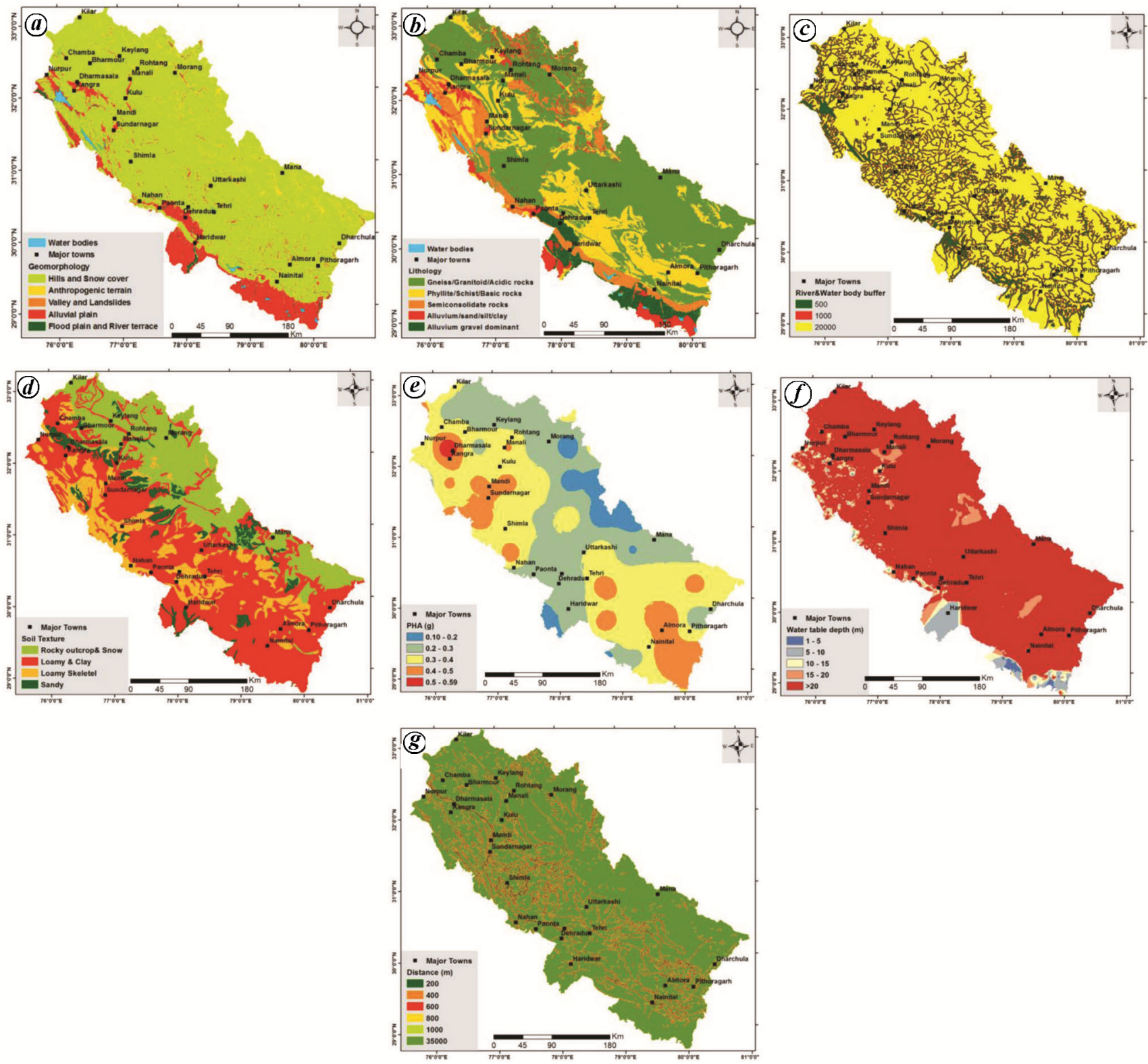

Figure 2. Thematic layers used for assessment of liquefaction susceptibility (LS): (a) geomorphology, (b) lithology, (c) river and water body buffer, $(\boldsymbol{d})$ soil texture, $(\boldsymbol{e})$ peak horizontal acceleration ${ }^{35},(\boldsymbol{f})$ water table depth and $(\boldsymbol{g})$ geological structure buffer.

with other features such as topographic slope and distance to the closest river $^{33}$. Soil surface texture is an important factor to be considered in the liquefaction susceptible model ${ }^{19,34}$. Ground shaking and intensity maps of earthquakes are necessary for liquefaction analysis, since ground shaking can increase the pore water pressure increasing liquefaction hazard ${ }^{19}$. For groundshaking parameter, we have included peak horizontal acceleration (PHA), which was derived based on deterministic seismic hazard assessment ${ }^{35}$. The thematic layers used in the present study are WTD, river and water body buffer zones, geomorphology, geology, PHA, soil and geological fault buffer on $1: 50,000$ scale (Figure 2).
Grid size of the thematic layers is $1 \mathrm{~km} \times 1 \mathrm{~km}$. Figure 3 depicts a flowchart of the methodology. Table 1 enunciates the importance of thematic layers and their control on liquefaction effects.

\section{Liquefaction susceptibility mapping using AHP}

Once all the layers are generated with the same geospatial connotation, the next step is the thematic integration of layers by multi-criteria weightage analysis. We have used Analytical Hierarchy Process (AHP) for estimation of weights $^{36}$. This is a well-known methodology for 
RESEARCH ARTICLES

Table 1. Data layers used for integration and their importance

\begin{tabular}{|c|c|c|}
\hline Thematic layer & Importance with respect to liquefaction & Data source \\
\hline Geomorphology & $\begin{array}{l}\text { It plays a key role in liquefaction assessment. Features such as } \\
\text { younger alluvial plains and floodplains are more susceptible to } \\
\text { liquefaction. The liquefaction-susceptible areas can be identified } \\
\text { by detailed analysis of geologic and geomorphic units }{ }^{45-47} \text {. The } \\
\text { geomorphology layer has been classified into (i) hills and snow } \\
\text { cover, (ii) anthropogenic terrain, (iii) valleys and landslides, } \\
\text { (iv) alluvial plains and (v) floodplains and river terrace. Figure } \\
2 a \text { shows the classified map. }\end{array}$ & $\begin{array}{l}\text { National Geomorphology and lineament } \\
\text { Mapping (NGLM) }{ }^{48,49} \text {. The NGLM project } \\
\text { was carried out under the National } \\
\text { Resource Census (NRC) by National } \\
\text { Remote Sensing Centre (NRSC) in } \\
\text { collaboration with the Geological Survey } \\
\text { of India. }\end{array}$ \\
\hline Geology & $\begin{array}{l}\text { The depositional environment also affects the liquefaction } \\
\text { susceptibility. Due to lack of compaction in younger geologic } \\
\text { features, they are more prone to liquefaction than the older ones. } \\
\text { The Uttarakhand and Himachal Pradesh Himalayas are } \\
\text { composed of metamorphic, volcanic, alkaline, granitoid, } \\
\text { unconsolidated and semi-consolidated rocks. The northern parts } \\
\text { of these states are covered by glaciated terrain. Unconsolidated } \\
\text { and semi-consolidated lithologies are moderate to highly prone } \\
\text { to liquefaction. The lithology map is classified as: (i) } \\
\text { gneiss, granitoids and acidic rocks, (ii) phyllite, schist and basic } \\
\text { rocks, (iii) semiconsolidated rocks, (iv) alluvium sand/silt/ } \\
\text { clay, and (v) alluvium gravel-dominant (Figure } 2 b \text { ). }\end{array}$ & $\begin{array}{l}\text { Rajiv Gandhi National Drinking Water } \\
\text { Mission (RGNDWM) database of NRSC. }\end{array}$ \\
\hline $\begin{array}{l}\text { River and waterbody buffer } \\
\text { (RWB) }\end{array}$ & $\begin{array}{l}\text { Liquefaction is more predominant along the rivers, lakes and } \\
\text { ponds }{ }^{12} \text {. The Himalayas are the source of major rivers in India } \\
\text { and along these rivers there are numerous sand deposits which } \\
\text { may cause sand boils and lateral spreading during an earthquake. } \\
\text { Thus multi-ring buffers have been created around the river and } \\
\text { water bodies using ArcGIS software. Therefore, we have } \\
\text { assigned weights up to } 1 \mathrm{~km} \text { with an interval of } 500 \mathrm{~m} \text {, and } \\
\text { the remaining area is considered as null value. Figure } 2 c \text { shows } \\
\text { the classes of buffer zones. }\end{array}$ & NGLM $^{48,49}$. \\
\hline Soil texture & $\begin{array}{l}\text { Loamy soils (composed of sand, silt and a small amount of clay) } \\
\text { and sandy soils have better drainage and infiltration capability of } \\
\text { water than silt and clay-rich soils. In the present study, the soil } \\
\text { map has been reclassified into (i) rocky outcrop and snow, (ii) } \\
\text { loamy and clay, (iii) loamy-skeletal and (iv) sandy soil. As the } \\
\text { soil map has been classified according to its contribution to } \\
\text { liquefaction (Figure } 2 d \text { ). }\end{array}$ & National Bureau of Soil Surveys (NBSS) $)^{50}$ \\
\hline $\begin{array}{l}\text { Peak horizontal } \\
\text { acceleration (PHA) }\end{array}$ & $\begin{array}{l}\text { Several probabilistic seismic hazard assessment (PSHA) and } \\
\text { deterministic seismic hazard assessment (DSHA) studies have } \\
\text { been carried out in the Northwest Himalayas }{ }^{35,43} \text {. In the present } \\
\text { study, we have used PHA map which has been modified from } \\
\text { Shankar and Shubham (Figure } 2 e)^{35} \text {. }\end{array}$ & Shankar and Shubham ${ }^{35}$ \\
\hline Water table depth (WTD) & $\begin{array}{l}\text { Depth to groundwater is an important parameter for liquefaction } \\
\text { susceptibility because liquefaction occurs in water-saturated } \\
\text { materials. Areas with }<10 \mathrm{~m} \text { groundwater table are more } \\
\text { susceptible to liquefaction }{ }^{1,6} \text {. We have used interpolated } \\
\text { groundwater table depth values in the present study. The } \\
\text { WTD map has been classified as depicted in Figure } 2 f \text {. }\end{array}$ & $\begin{array}{l}\text { WTD values were collected from wells under } \\
\text { the RGNDWM project of NRSC. }\end{array}$ \\
\hline Geological structure buffer & $\begin{array}{l}\text { Geological structures and fractures constitute secondary porosity. } \\
\text { In the present study, lineament buffers wereused as an input for } \\
\text { liquefaction susceptibilityassessment. The buffer zones have } \\
\text { been created with an interval of } 200 \mathrm{~m} \text { up to } 1 \mathrm{~km} \text {. Figure } 2 \mathrm{~g} \\
\text { depicts the lineament map. }\end{array}$ & NGLM $^{48,49}$ \\
\hline
\end{tabular}

complex decision-making required for multilayer integration. Herein, it is mainly defined based on correlation of LS with respect to input parameters.

AHP is useful for assigning relative weights to multiple layers depending upon its influence on a particular phenomenon such as liquefaction. The ranks are assigned based on published information and experience of the subject expert in the related domain, explained in the followed section. A comparison matrix was prepared using a $1-5$ scale; 1 is of least importance and 5 is of 
Table 2. Pairwise matrix table of the main variables

\begin{tabular}{lccccccc}
\hline Parameter & WTD & PHA & Structure & Soil & RWB & Lithology & Geomorphology \\
\hline WTD & 1 & 1 & 2 & 3 & 4 & 4 & 5 \\
PHA & 1 & 1 & 2 & 2 & 3 & 4 & 4 \\
Structure & $1 / 2$ & $1 / 2$ & 1 & 2 & 3 & 3 & 4 \\
Soil & $1 / 3$ & $1 / 2$ & $1 / 2$ & 1 & 1 & 3 & 4 \\
RWB & $1 / 4$ & $1 / 3$ & $1 / 3$ & 1 & 1 & 2 & 3 \\
Lithology & $1 / 4$ & $1 / 4$ & $1 / 3$ & $1 / 3$ & $1 / 2$ & 1 & 2 \\
Geomorphology & $1 / 5$ & $1 / 4$ & $1 / 4$ & $1 / 4$ & $1 / 3$ & $1 / 2$ & 1 \\
\hline
\end{tabular}

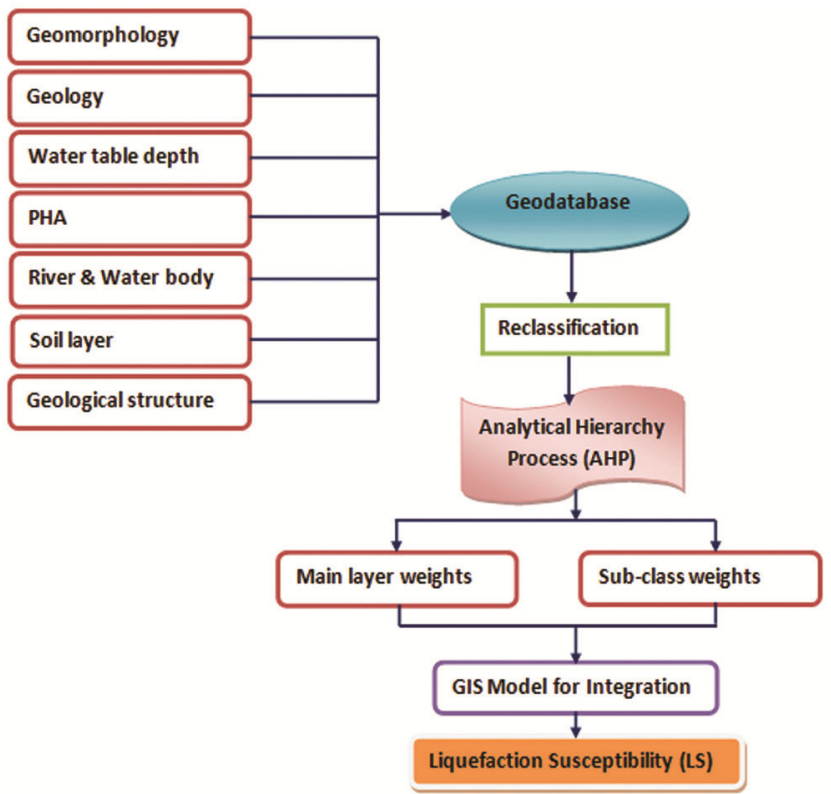

Figure 3. Methodology flowchart of LS mapping.

extreme importance ${ }^{36}$. Layers less susceptible to liquefaction were assigned inverse of 1-5 values. The comparison matrix of many layers depict relative influence of the class on LS (Table 2).

For example, if one considers WTD and geomorphology, the former (score 5) is more susceptible than the latter (score 1/5). This is because the areas with shallow WTD are more prone to liquefaction since topsoil can saturate easily. The weights assigned to each class and their factors are normalized using the methodology of Saaty ${ }^{36}$. Further, a consistency ratio (CR) is estimated using eq. (1)

$$
\mathrm{CR}=\frac{\mathrm{CI}}{\mathrm{RI}}
$$

where $\mathrm{CI}$ is the consistency index calculated using eq. (2) below, RI is the random index with a value of 1.32 for seven layers ${ }^{36}$

$$
\mathrm{CI}=\frac{\lambda-n}{n-1}
$$

where $\lambda$ is the eigenvalue calculated from the weight matrix and $n$ is the number of layers. The combined individual weights and subclass weights are estimated using AHP (Table 3) and integrated in GIS to derive LS map, based on eq. (3) and Figure 4

$$
\begin{aligned}
\mathrm{LS}= & \left(\mathrm{WTD}_{\mathrm{w}} * \mathrm{WTD}_{\mathrm{sw}}+\mathrm{RWB}_{\mathrm{w}} * \mathrm{RWB}_{\mathrm{sw}}\right. \\
& +\mathrm{GEOM}_{\mathrm{w}} * \mathrm{GEOMsw}+\mathrm{LITHO}_{\mathrm{w}} * \mathrm{LITHO}_{\mathrm{sw}} \\
& +\mathrm{PHAw} * \mathrm{PHA}_{\mathrm{sw}}+\mathrm{SOIL}_{\mathrm{w}} * \mathrm{SOIL}_{\mathrm{sw}} \\
& \left.+\mathrm{GS}_{\mathrm{w}} * \mathrm{GS}_{\mathrm{sw}}\right) / \sum W
\end{aligned}
$$

where $w$ is the weight of the individual layers, sw is subclass weight, RWB is river and water body buffer, GEOM is geomorphology, LITHO is lithology and GS is geological structure.

\section{Results and discussion}

In terms of lithology, the study area of Uttarakhand and Himachal Pradesh consists of hard-rock terrain (mostly metamorphic) in the northern part. The greater Himalayas mainly consists of gneiss, schist and phyllite rocks. The Siwaliks contain semiconsolidated rocks and the foothills consist of alluvium and gravel dominant/sand/silt/clay. The geomorphology of the area comprises floodplains, river terrace and alluvial plains in foothills of the Himalayas. The northern part of the study area mainly consists of dissected hills and valleys.

The groundwater level of this region varies between 1 and $100 \mathrm{~m}$ and in the foothills of the Himalayas, WTD is generally $<15 \mathrm{~m}$, which makes the soil highly prone to liquefaction. In the present study, WTD has been grouped into five classes with an interval of $5 \mathrm{~m}$. Relative weights were calculated from the pairwise matrix based on AHP methodology. The weights were decided based on how much the layer is contributing towards liquefaction. The weights obtained in descending order are WTD (0.28), PHA (0.24), structure (0.17), soil (0.12), RWS (0.091), lithology (0.06) and geomorphology (0.04). WTD has been assigned with maximum weight since the level of 
RESEARCH ARTICLES

Table 3. Main and subclass layer weights with consistency ratio (CR) values estimated from analytical hierarchy process (AHP)

\begin{tabular}{|c|c|c|c|c|c|c|}
\hline Main variable & CR & Weight & Subclass & CR & Weight & $\begin{array}{l}\text { Cumulative } \\
\text { weight }\end{array}$ \\
\hline \multirow[t]{5}{*}{ WTD (m) } & 0.03 & 0.28 & $0-5$ & 0.02 & 0.33 & 0.090 \\
\hline & & & $5-25$ & & 0.29 & 0.079 \\
\hline & & & $25-35$ & & 0.19 & 0.053 \\
\hline & & & $35-50$ & & 0.11 & 0.030 \\
\hline & & & $>45 \mathrm{~m}$ & & 0.09 & 0.024 \\
\hline \multirow[t]{5}{*}{ PHA (g) } & & 0.24 & $0.1-0.2$ & 0.02 & 0.33 & 0.079 \\
\hline & & & $0.21-0.3$ & & 0.29 & 0.070 \\
\hline & & & $0.31-0.4$ & & 0.19 & 0.046 \\
\hline & & & $0.41-0.5$ & & 0.11 & 0.026 \\
\hline & & & $0.51-0.6$ & & 0.09 & 0.021 \\
\hline \multirow[t]{5}{*}{ Structure (m) } & & 0.17 & 200 & 0.02 & 0.302 & 0.053 \\
\hline & & & 400 & & 0.262 & 0.046 \\
\hline & & & 800 & & 0.124 & 0.022 \\
\hline & & & 1000 & & 0.077 & 0.013 \\
\hline & & & $>1000$ & & 0.050 & 0.009 \\
\hline \multirow[t]{4}{*}{ Soil } & & 0.12 & Sandy & 0.03 & 0.39 & 0.047 \\
\hline & & & Loamy-skeletal & & 0.37 & 0.045 \\
\hline & & & Loamy, clay & & 0.16 & 0.019 \\
\hline & & & Glaciers and rock outcrops & & 0.07 & 0.009 \\
\hline \multirow[t]{3}{*}{ RWB (m) } & & 0.09 & 500 & 0.03 & 0.568 & 0.052 \\
\hline & & & 1000 & & 0.334 & 0.030 \\
\hline & & & $>1000$ & & 0.098 & 0.009 \\
\hline \multirow[t]{4}{*}{ Lithology } & & 0.06 & Alluvium gravel-dominant & 0.02 & 0.33 & 0.019 \\
\hline & & & $\begin{array}{l}\text { Alluvium clay/sand/silt-dominant, colluvium-clay/ } \\
\text { silt-dominant, clay, unconsolidated angular fragments }\end{array}$ & & 0.29 & 0.017 \\
\hline & & & $\begin{array}{l}\text { Basic rocks, cavernous limestone, consolidated-shale with } \\
\text { limestone/sandstone, boulder conglomerate, consolidated } \\
\text { assorted material, basal/meta basalt, phyllite, schist, } \\
\text { undifferentiated meta basics, undifferentiated } \\
\text { metasediments }\end{array}$ & & 0.12 & 0.007 \\
\hline & & & $\begin{array}{l}\text { Gneiss, granites/acidic rocks, granitoid gneiss, marble/ } \\
\text { crystalline limestone, quartzite, paragneiss, shale, slate, } \\
\text { thick-bedded/massive limestone/dolomite, thick- } \\
\text { bedded/massive sandstone/quartzite, undifferentiated } \\
\text { metamorphic rocks }\end{array}$ & & 0.07 & 0.004 \\
\hline \multirow[t]{5}{*}{ Geomorphology } & & 0.04 & Active and old floodplains, river terrace & 0.02 & 0.34 & 0.014 \\
\hline & & & Piedmont alluvial plain, younger and older alluvial plains & & 0.31 & 0.013 \\
\hline & & & $\begin{array}{l}\text { Intermontane valley, pediment pediplain complex, strath } \\
\text { terrace, talus/scree, valley, landslides }\end{array}$ & & 0.20 & 0.008 \\
\hline & & & $\begin{array}{l}\text { Anthropogenic terrain, road-cutting, piedmont slope, } \\
\text { active quary }\end{array}$ & & 0.09 & 0.004 \\
\hline & & & $\begin{array}{l}\text { Glacial terrain, highly/moderately/low dissected hills and } \\
\text { valleys, hills, kame terrace, ridge, snow cover, strath } \\
\text { terrace, strike ridge, dams and reservoirs }\end{array}$ & & 0.06 & 0.002 \\
\hline
\end{tabular}

groundwater plays a vital role in liquefaction ${ }^{1,4,37}$. An inclusion of ground-shaking parameter is an important variable in $\mathrm{LS}^{19}$. So, we have given second priority to PHA. This is followed by soil texture and faults in order of priority, because liquefaction may occur due to sec- ondary porosity/permeability effects which are induced by geological structures. Minimum weight has been assigned to geomorphology (Figure 4). We have estimated $\mathrm{CR}$ as 0.03 , which indicates that the assigned weightages are consistent relative to each other. Table 3 


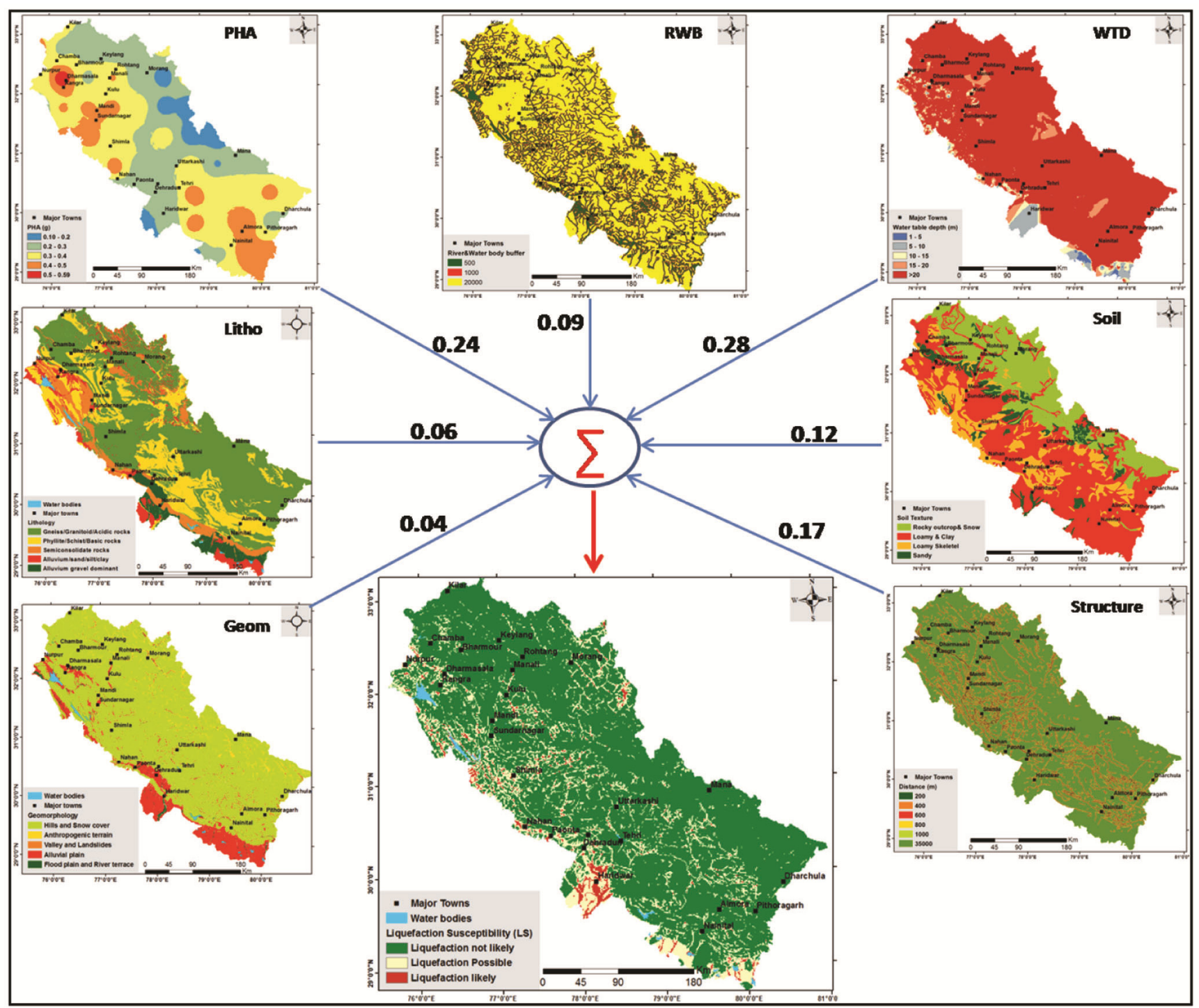

Figure 4. Integration of all thematic layers with different weights: geomorphology $(0.04)$, lithology $(0.06)$, PHA $(0.24)^{35}$, river and water body buffer (0.09), water table depth (0.28), soil (0.12) and geological structure $(0.17)$.

shows weights of main layers and grouping of each subclass layer and its weights which were calculated by AHP with an admissible CR value.

The final LS map was classified into three zones such as liquefaction-likely, liquefaction-possible and liquefaction-not-likely (Figure 5). The foothills of the Himalaya are mostly distributed with alluvium and hence are more prone to LS. Thus, this region is mostly identified with liquefaction-likely and liquefaction-possible areas with presence of river bodies and associated floodplains. High LS is also observed at river terraces. Higher Himalayas, with highly dissected hills and valleys, was found to be less susceptible to liquefaction. Towns in the foothills of the Himalayas such as Dehradun and Haridwar are near river bodies with shallow groundwater table and consist of alluvial plains. Hence, these towns were identified with liquefaction-likely and liquefaction-possible areas (Figure 6).
Though field verification of such liquefaction sites is not possible in the absence of a commensurate magnitude of earthquakes, historical records from past earthquakes may be referred to gather evidence for the same. Such records suggest that there have been two prominent liquefaction damage sites due to the 1803 Garhwal earthquake in the foothills or Indo-Gangetic Plains, i.e. Mathura (77.6737E and $27.4924 \mathrm{~N}$ ) located $\sim 150 \mathrm{~km}$ south of Delhi and Biharigarh $\left(30^{\circ} 05^{\prime} 56.4^{\prime \prime} \mathrm{N}, 77^{\circ} 49^{\prime} 13.7^{\prime \prime} \mathrm{E}\right)$ located $\sim 45 \mathrm{~km}$ from Dehradun ${ }^{25,26}$. Thakur ${ }^{38}$ reported that along the Himalayan Frontal Thrust (HFT) zone adjoining to the Ganga-Yamuna plains is a thick cover $(\sim 3 \mathrm{~km})$ of alluvium sediments that are likely to be liquefactionprone. In addition, during the 1897 Shillong earthquake, liquefaction sites were identified in analogous locations along the Brahmaputra River ${ }^{27}$. The microseismic field observations conducted after the 1999 Chamoli earthquake recorded that damage of intensity VIII was 


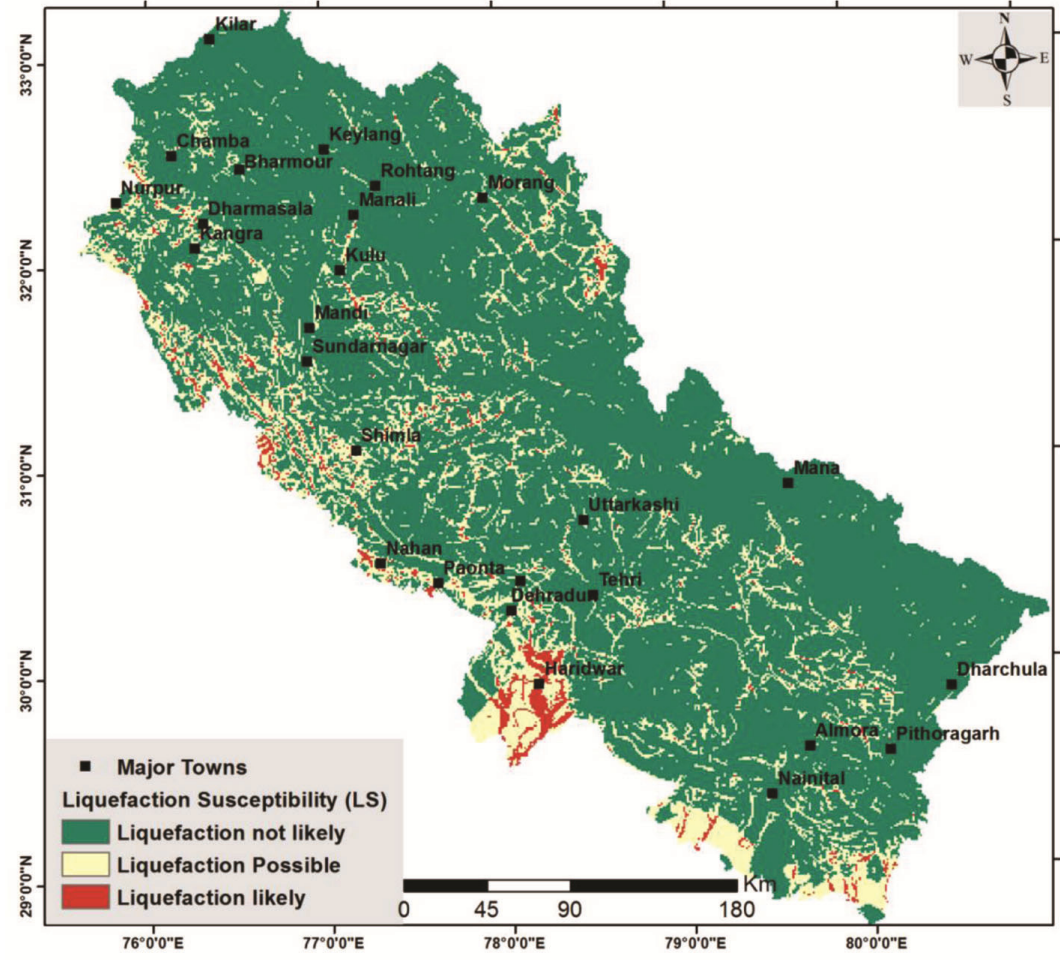

Figure 5. Preliminary LS map of Uttarakhand and Himachal Pradesh.
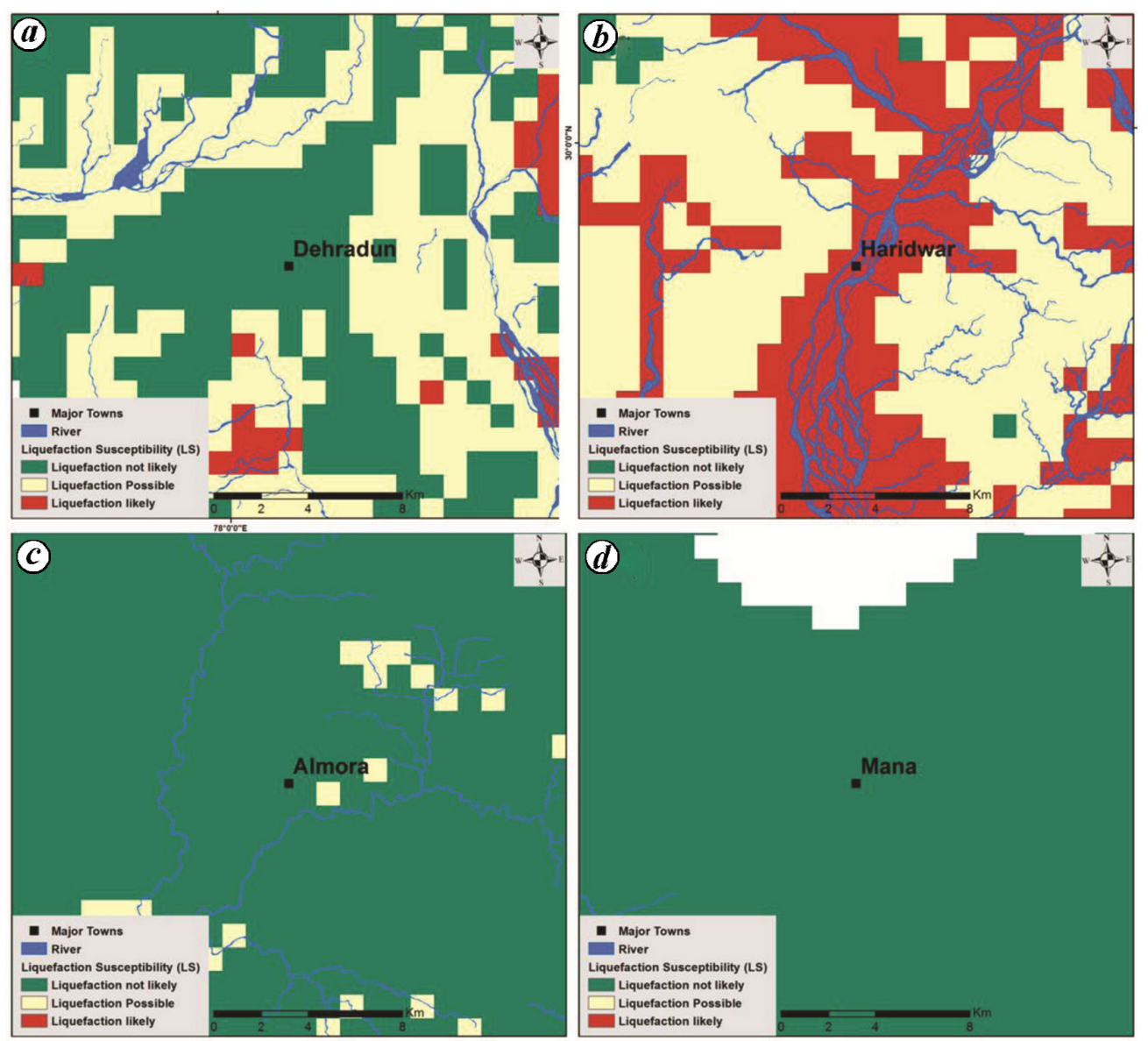

Figure 6. LS maps of different cities in the present study: (a) Dehradun (b) Haridwar, (c) Almora and (d) Mana. 


\section{RESEARCH ARTICLES}

confined to the right bank of river Alaknanda ${ }^{39}$. Similar liquefaction sites were also observed during the 2005 Kashmir earthquake at Simbala village located about $25 \mathrm{~km}$ from Jammu city in the Indo-Gangetic Plain to the left bank of River Tawi ${ }^{40}$. On the other hand, further south and east of the Dehradun city, liquefaction-likely and liquefaction-possible zones were mapped. The Dehradun site-response studies showed that south and southwestern regions of Dehradun city were classified under National Earthquake Hazard Reduction Program (NEHRP) site class E $(<180 \mathrm{~m} / \mathrm{s})$ and class D $(180$ $360 \mathrm{~m} / \mathrm{s}$ ), which indicates less stiffness of the soils and proneness to liquefaction ${ }^{41-43}$. In the present study, liquefaction-likely and liquification-possible areas (Dharmawala and Doiwala) of Doon valley near the Main Boundary Thrust (MBT) match well with such observations $^{44}$.

The higher Himalayas consists of metamorphic rocks with high elevation and high WTD. Hence, towns such as Almora and Mana have been identified with liquefactionnot-likely areas (Figure 6). A regional survey of liquefaction potential has not been carried out so far in the Himalayas. Hence the map generated from the present study can act as a first reference for detailed analysis in the region.

\section{Conclusion}

Regional LS map of Uttarakhand and Himachal Pradesh was prepared by integration of geospatial data such as geomorphology, lithology, soil, WTD, river and water body buffer, PHA and geological structure buffer using AHP. The resultant LS map of the region has been divided into three classes, namely liquefaction-not-likely, liquefaction-possible and liquefaction-likely. The Doon valley and foothills of the Himalayas are observed to fall under liquefaction-likely and liquefaction-possible areas due to their alluvial substrate and proximity to rivers. The major cities of Dehradun, Haridwar, Nahan, etc. fall in this region. Cities and towns within the mountains generally fall in liquefaction-not-likely category. However, Uttarkashi town situated in a wide river valley, has liquefaction-possible and liquefaction-likely areas. LS maps of areas around a few cities such as Dehradun, Haridwar, Almora and Mana clearly show the difference in liquefaction in the valleys, plains (Dehradun and Haridwar) and mountain areas (Almora and Mana). The classified potential zones were correlated with past liquefaction sites of the Himalayas, which shows that higher potential zones such as the foothills and along the river bodies match with past earthquake liquefaction sites.

We have delineated the regional-level LS zones based on geospatial analysis. A limitation of this study is that the accuracy of the same may not be equivalent to detailed liquefaction studies carried out using field-based measurements. Also, we have not considered other factors which affect liquefaction (e.g. plasticity index, effective stress) in the model. However, rapid assessment as presented in this study, can be useful in areas where detailed liquefaction survey needs to be carried out. Further, the regional-level map may be used for broad delineation of the potentially hazardous zone in which mitigation measures are necessary. Lastly, the regional LS map may serve as a general guideline for structural engineers and geotechnical engineers prior to planning and construction of civil structures.

1. Youd, T. L., Liquefaction, flow and associated ground failure. Circular 688, US Geological Survey, 1973.

2. Sonmez, H. and Gokceoglu, C., A liquefaction severity index suggested for engineering practice. Environ. Geol., 2005, 48(1), 81-91.

3. Seed, H. B. and Idriss, I. M., Simplified procedure for evaluating soil liquefaction potential. J. Soil Mech. Found. Div., ASCE, 1971, 97(9), 1249-1273.

4. Iwasaki, T., Tokida, K., Tatsuoka F., Watanabe, S., Yasuda, S. and Sato, H., Microzonation for soil liquefaction potential using simplified methods. In Proceedings of the third International Earthquake Microzonation Conference, 1982, vol. 3, pp. 13191330 .

5. Seed, H. B., Tokimatsu, K., Harder Jr, L. F. and Chung, R., Influence of SPT procedures in soil liquefaction resistance evaluations. J. Geotech. Eng. Div., 1985, 111(12), 1425-1445.

6. Youd, T. L. and Idriss, I. M., Liquefaction resistance of soils: summary report from the 1996 NCEER and 1998 NCEER/NSF workshops on evaluation of liquefaction resistance of soils. J. Geotech. Geoenviron. Eng., 2001, 127(4), 297-313.

7. Youd, T. L. et al., Liquefaction resistance of soils: summary report from the 1996 NCEER 14 and 1998 NCEER/NSF workshop on evaluation of liquefaction resistance of soils. J. Geotech. Geoenviron. Eng., 2001, 127(10), 817-833.

8. Youd, T. L. and Perkins, D. M., Mapping liquefaction induced ground failure potential. J. Geotech. Eng. Div., 1978, 104(4), 433446.

9. Chung, J. W., Rogers, J. D., P. E. and ASCE, M., Simplified method for spatial evaluation of liquefaction potential in the St. Louis Area. J. Geotech. Geoenviron. Eng., 2011, 137, 505-515; doi:10.1061/(ASCE) GT.1943-5606.0000450.

10. Kramer, S. L., Geotechnical Earthquake Engineering, Prentice Hall, Upper Saddle River, NJ, USA, 1996.

11. Tuttle, M., Chester, J., Lafferty, R., Dyer-Williams, K. and Cande, B., Paleoseismology study northwest of the New Madrid Seismic Zone. US Nuclear Regulatory Commission, 1999.

12. Marcuson III, W. F, Definition of terms related to liquefaction. J. Geotech. Eng. Div., ASCE, 1978, 104(9), 1197-1200.

13. Wakamatsu, K., Evaluation of liquefaction susceptibility based on detailed geomorphological classification. In Proceedings of Technical Papers of Annual Meeting, Architectural Institute of Japan, 1992, vol. B, pp. 1443-1444.

14. Torres, R. C., Paladio, M. L., Punongbayan, R. S. and Alonso, R. A., Liquefaction inventory and mapping in the Philippines. In National Disaster Mitigation in the Philippines. Proceedings of the National Conference on Natural Disaster Mitigation, DOSTPHIVOLCS, Philippine, 1994, pp. 45-60.

15. Akin, K. M., Topal, T. and Kramer, S. L., A newly developed seismic microzonation model of Erbaa (Tokat, Turkey) located on seismically active eastern segment of the North Anatolian Fault Zone (NAFZ). Nat. Hazards, 2013, 65, 1411-1442; doi:10.1007/ s11069-012-0420-1. 
16. Taskin, B., Sezen, A. and Tugsal, U. M., The aftermath of 2011 Van earthquakes: evaluation of strong motion, geotechnical and structural issues. Bull. Earthq. Eng., 2013, 11, 285.

17. Holzer, T. L., Noce, T. E. and Bennett, M. J., Scenario liquefaction hazard maps of Santa Clara Valley, northern California. Bull. Seismol. Soc. Am., 2009, 99, 367-381.

18. Brankman, C. M., amd Baise, L. G., Liquefaction susceptibility mapping in Boston, Massachusetts. Environ. Eng. Geosci., 2008, 14, 1-16.

19. Zhu, J., Baise, L. G. and Thompson, E. M., An updated geospatial liquefaction model for global application. Bull. Seismol. Soc. Am., 2017, 107(3), 1365-1385; doi:10.1785/0120160198.

20. Baise, L. G., Daley, D., Zhu, J., Thompson, E. M. and Knudsen, K., Geospatial liquefaction hazard model for Kobe, Japan and Christchurch, New Zealand. Seismol. Res. Lett., 2012, 83, 458.

21. Ganapathy, G. P. and Rajawat, A. S., Evaluation of liquefaction potential hazard of Chennai City, India: using geological and geomorphological characteristics. Nat. Hazards, 2012, 64(2), 1717-1729.

22. Zhu, J., Daley, D., Baise, L. G., Thompson, E. M., Wald, D. J. and Knudsen, K. L., A geospatial liquefaction model for rapid response and loss estimation. Earthq. Spectra, 2015, 31, 18131837.

23. Puri, N. and Jain, A., Preliminary investigation for screening of liquefiable areas in Haryana state, India. ISET J. Earthq. Technol., 2014, 51(1-4), 19-34.

24. Sekac, T., Jana, S. K., Pal, I. and Pal, D. K., A GIS based approach into delineating liquefaction susceptible zones through assessment of site-soil-geology - a case study of Madang and Morobe Province in Papua New Guinea (PNG). Int. J. Innov. Res. Sci., Eng. Technol., 2016, 3(8), 6616-6629.

25. Oldham, T. A., catalogue of Indian earthquakes from the earliest to the end of 1869. Mem. Geol. Surv. India, 1883, 19(1), 163-215.

26. Rajendran, C. P., Rajendran, K., Sanwal, J. and Sandiford, M. Archeological and historical database on the medieval earthquakes of the Central Himalaya: ambiguities and inferences. Seismol. Res. Lett., 2013, 84(6), 1098-1108.

27. Hough, S. E. and Bilham, R., Site response of the Ganges basin inferred from re-evaluated macroseismic observations from the 1897 Shillong, 1905 Kangra, and 1934 Nepal earthquakes. J. Earth Syst. Sci., 2008, 117(S2), 773-782.

28. Rajendran, C. P., John, B., Rajendran, K. and Sanwal, J., Liquefaction record of the great 1934 earthquake predecessors from the north Bihar alluvial plains of India. J. Seismol., 2016; doi:10.1007/s10950-016-9554-z.

29. Wadia, D. N., The Geology of India, Macmillan, New York, USA, 1957, 3rd edn., pp. 353, 383.

30. Gansser, A., Geology of the Himalayas, Interscience, New York, USA, 1964, p. 289

31. Valdiya, K. S., Geology of the Kumaun Lesser Himalaya, The Himachal Press, Wadia Institute of Himalayan Geology, Dehradun, 1980, p. 219

32. BIS IS 1893-2002 (Part 1): Indian standard criteria for earthquake resistant design of structures. Part 1 -general provisions and buildings. Bureau of Indian Standards, New Delhi, 2002.

33. Knudsen, K. and Bott, J., Geologic and geomorphic evaluation of liquefaction case histories for rapid hazard mapping. Seismol. Res. Lett., 2011, 82, 334 .

34. Idriss, I. M. and Boulanger, R. W., Semi-empirical procedures for evaluating liquefaction potential during earthquakes. Soil Dyn. Earthq. Eng., 2006, 26, 115-130.

35. Shankar, D. and Shubham, On the seismic hazard in Himachal Pradesh and Utarakhand States. Geoscience, 2018, 8(2), 21-31.

36. Saaty, T. L., The Analytic Hierarchy Process, McGraw-Hill International, New York, USA, 1980.

37. Obermeier, S. F., Use of liquefaction induced features for seismic analysis - an overview of how seismic liquefaction features can be distinguished from other features and how their regional distribution and properties of source sediment can be used to infer the location and strength of holocene Paleo-earthquakes. Eng. Geol., 1996, 44, 1-76.

38. Thakur, V. C., Active tectonics of Himalayan Frontal Thrust and seismic hazard to Ganga Plain. Curr. Sci., 2004, 86(11), 1554 1560 .

39. Mahajan, A. K. and Virdi, N. S., Macroseismic field generated by 29 March 1999 Chamoli earthquake and its seismotectonics. J. Asian Earth Sci., 2001, 19, 507-516.

40. Malik, J. N., Sahoo, A. K., Shah, A. A., Rawat, A. and Chaturved, A., Farthest recorded liquefaction around Jammu caused by 8 October 2005, Muzaffarabad earthquake of $M_{W}=7.6$. J. Geol. Soc. India, 2007, 69, 39-61.

41. Mahajan, A. K., Slob, S., Ranjan, R., Sporry, R., Champati Ray, P. K. and Van Westen, C. J., Seismic microzonation of Dehradun City using geophysical and geotechnical characteristics in the upper $30 \mathrm{~m}$ of soil column. J. Seismol., 2007, 11, 355-370; doi:10.1007/s10950-007-9055-1.

42. Mahajan, A. K., NEHRP soil classification and estimation of 1-D site effect of Dehradun fan deposits using shear wave velocity. Eng. Geol., 2009, 104, 232-240.

43. Mahajan, A. K., Thakur, V. C., Sharma, M. L. and Chauhan, M., Probabilistic seismic hazard map of NW Himalaya and its adjoining area, India. Nat. Hazards, 2010, 53, 443-457; doi:10.1007/ s11069-009-9439-3.

44. Sathyaseelan, R., Mundepi, A. K. and Kumar, N., Quantifying seismic vulnerability, dynamical shear strain and liquefaction of the Quaternary deposits in the Doon valley near the Main Boundary Thrust in the Northwest Himalaya, India. Quaternary Int., 2017, 462, 162-175.

45. Kotoda, K., Wakamatsu, K. and Oya, M., Mapping liquefaction potential based on geomorphological land classification. In Proceedings of Ninth World Conference on Earthquake Engineering, Tokyo-Kyoto, Japan, 1988, vol. 3, p. 195.

46. Wakamatsu, K., Akio, Y. and Ichiro, T., Geomorphological criteria for evaluating liquefaction potential considering the level-2 ground motion in Japan (26 March 2001). In International Conference Recent Advances in Geotechnical Earthquake Engineering Soil Dynamics, 2001; paper http://scholarsmine.mst.edu/icrageesd/ 04icrageesd/session $04 / 3$

47. Witter, R. C. et al., Maps of Quaternary deposits and liquefaction susceptibility in the central San Francisco Bay region, California. US Geol Survey Open-File Report 06-1037, 2006; http://pubs. usgs.gov/of/2006/1037/

48. GSI and NRSC, Manual for national geomorphological and lineament mapping on $1: 50,000$ scale. (Document control number: NRSC-RS\&GISAA-ERG-G\&GD-FEB' 10-TR149), National Remote Sensing Centre, Hyderabad, 2010.

49. Martha, T. R., Ghosh, D., Kumar, K. V., Lesslie, A. and Ravi Kumar, M. V., Geospatial technologies for national geomorphology and lineament mapping project - a case study of Goa state. J. Indian Soc. Remote Sensing, 2013, 41(4), 905-920; doi:10.1007/s12524012-0260-1.

50. http//nbsslup.in

ACKNOWLEDGEMENTS. This study is a part of a 'Technology Development Project' of NRSC/ISRO. We thank the Director (NRSC, Hyderabad) and Deputy Director (Remote Sensing Applications Area, NRSC) for encouragement and support. We also thank the anonymous reviewers for their constructive comments that helped improve the manuscript.

Received 9 October 2018; revised accepted 21 February 2019

doi: $10.18520 / \mathrm{cs} / \mathrm{v} 116 / \mathrm{i} 11 / 1868-1877$ 